This is a revised personal version of the text of the final journal article, which is made available for scholarly purposes only, in accordance with the journal's author permissions. The full citation is:

Suhartini, Sri, Sonia Heaven, and Charles J. Banks, Comparison of mesophilic and thermophilic anaerobic digestion of sugar beet pulp: Performance, dewaterability and foam control, Bioresource Technology, Volume 152, January 2014, Pages 202-211, ISSN 0960-8524, 10.1016/j.biortech.2013.11.010.

(http://www.sciencedirect.com/science/article/pii/S0960852413017148)

\title{
Comparison of mesophilic and thermophilic anaerobic digestion of sugar beet pulp: Performance, dewaterability and foam control
}

Sri Suhartini ${ }^{1,2 *}$, Sonia Heaven ${ }^{1}$ and Charles J. Banks ${ }^{1}$

1 Faculty of Engineering and the Environment, University of Southampton, Southampton SO17 1BJ, UK

2 Department of Agricultural Industry Technology, Faculty of Agricultural Technology, University of Brawijaya, Malang 65145, Indonesia

\begin{abstract}
Digestion of sugar beet pulp was assessed in relation to biogas and methane production, foaming potential, and digestate dewaterability. Four 4-litre working volume digesters were operated mesophilically $\left(37 \pm 0.5^{\circ} \mathrm{C}\right)$ and four thermophilically $\left(55 \pm 0.5^{\circ} \mathrm{C}\right)$ over three hydraulic retention times. Digesters were operated in duplicate at organic loading rates (OLR) of 4 and $5 \mathrm{~g}$ volatile solids $\mathrm{l}^{-1}$ day $^{-1}$ without water addition. Thermophilic digestion gave higher biogas and methane productivity than mesophilic and was able to operate at the higher OLR, where mesophilic digestion showed signs of instability. Digestate dewaterability was assessed using capillary suction time and frozen image centrifugation. The occurrence of, or potential for, stable foam formation was assessed using a foaming potential test. Thermophilic operation allowed higher loadings to be applied without loss of performance, and gave a digestate with superior dewatering characteristics and very little foaming potential.
\end{abstract}

Keywords: anaerobic digestion, sugar beet pulp, biogas, digestate, dewatering, foam formation

\section{Introduction}

Substantial quantities of Sugar Beet Pulp (SBP) arise from the processing of sugar beet, particularly in Europe and the USA, with the UK alone producing an average of 500,000 tonnes year ${ }^{-1}$ which at present is mainly used as cattle feed (British Sugar, 2011). SBP also has several other potential uses, such as the production of non-food grade xanthan gum (Yoo and Harcum, 1999), as a soil fertiliser (Medina et al., 2007), and as feedstock for anaerobic digestion (AD) to produce biogas as a renewable energy

\footnotetext{
*Corresponding author e-mail: ssuhartini@ub.ac.id; sh7@ soton.ac.uk; cjb@soton.ac.uk
} 
source (Ghanem et al., 1992; Hutnan et al., 2000; Koppar and Pullammanappallil, 2008; Labat et al., 1984; Polematidis et al., 2007). AD of crop residues can offer better revenue returns from energy production compared to the animal feed market, while providing a direct means of recycling nutrients to arable land (Parawira et al., 2008).

Major difficulties encountered when using SBP as a substrate for AD are the poor dewaterability of the digestate and the appearance of stable foam in the digesters, especially when they are highly loaded and operated at mesophilic temperatures $(\sim 37$

${ }^{\circ} \mathrm{C}$ ) (Brooks et al., 2008; Stoppok and Buchholz, 1985). Without an effective dewatering step the logistics of applying the digestate to agricultural land pose a significant economic and environmental challenge due to the high tonnages involved. This might be overcome if effective dewatering techniques could be found, or the digestate characteristics improved through process manipulation to allow the use of conventional dewatering technologies. Improved dewaterability would reduce sludge handling and minimise the volume for transportation, but would also require treatment of the dewatered liquor. Reducing the water retention properties of the digestate through process manipulation is also likely to contribute towards minimising the tendency for stable foam formation in the digester itself.

Factors that influence dewaterability are: particle size and composition of the feed substrate (Liming et al., 2009); operating temperature; and sludge age (Lovett et al., 1983) and formation of extracellular polymer (Mikkelsen and Keiding, 2002). Foaming appears to have a set of complex causes. It can be due to the presence of excessive numbers of filamentous bacteria (such as Gordonia and Microthrix); an excess of surface active agents (oils and grease); composition of and variation in the digester feedstock (Massart et al., 2006); unstable conditions due to shock loads or overloading (Speece, 2008); temperature fluctuations (Barber, 2005); hydrophobic substances; inadequate mixing; and the accumulation of acetic acid (Pagilla et al., 1997). In digesters treating wastewater biosolids, foaming usually occurs at an organic loading rate (OLR) higher than $4.5 \mathrm{~kg}$ volatile solids (VS) $\mathrm{m}^{-3} \mathrm{day}^{-1}$ (Brown, 2002). As a result of foaming there may be a fall in biogas or methane production, a decrease in volatile solids degradation (Barjenbruch and Kopplow, 2003), and the risk of blockage to gas outlets.

Studies on anaerobic digestion have considered single-stage and two-stage processes under a wide range of operational conditions, including variations in OLR, $\mathrm{pH}$ and temperature. These have shown that, although mesophilic digestion is generally considered more stable, thermophilic AD can give a higher rate of organic matter degradation with greater biogas production; and may offer a shorter retention time, the possibility of feeding at a higher OLR, and potentially better pathogen kill due to the higher temperature. Other benefits from thermophilic AD of certain feedstocks may include improved dewatering characteristics and prevention of the occurrence of foam (Chi et al., 2010).

The aim of the research was to compare the characteristics of thermophilic and mesophilic digestion of SBP in terms of process efficiency, stability, and digestate dewaterability. To the best of our knowledge this is the first work to have reported 
specifically on the digestate dewaterability characteristics or foam potential in thermophilic digestion of SBP.

\section{Materials and methods}

\subsection{Feedstock and inoculum}

Sugar beet pulp was collected fresh from British Sugar's Wissington Factory, Kings Lynn, UK, then packed into 4-litre containers and frozen at approximately $-20{ }^{\circ} \mathrm{C}$. Before feeding to the digesters the material was thawed for at least 24 hours at room temperature. The inoculum for the mesophilic digesters was prepared by mixing at a 1:1 volume ratio digestates taken from an anaerobic digester treating sugar beet pulp (British Sugar, Wissington, UK), and one treating municipal wastewater biosolids (Millbrook Wastewater Treatment Works, Southampton, UK). The thermophilic digesters used inoculum from the mesophilic municipal wastewater biosolids digester which was then acclimated to thermophilic conditions as described below.

\subsection{Experimental procedures}

Experiments were carried out in duplicate using four mesophilic $\left(37 \pm 0.5^{\circ} \mathrm{C}\right)$ and four thermophilic $\left(55 \pm 0.5^{\circ} \mathrm{C}\right)$ continuously-stirred tank reactor (CSTR) digesters, each with a 4-litre working volume (Fig. 1). Digester temperature was maintained by water circulating through an external heating coil. Semi-continuous operation was achieved by daily feeding of SBP, without any water addition, via a hole in the top plate; digestate was removed through an outlet port in the base plate immediately before feed addition. The digesters were connected to tipping-bucket gas counters with continuous data logging. Biogas productivity was measured continuously apart from a brief interval during feeding and digestate removal. Methane content was determined on a 24-hour composite gas sample taken once per week: this sample was also used for gas counter calibration. All gas volumes reported are corrected to standard temperature and pressure (STP) of $0{ }^{\circ} \mathrm{C}$ and $101.325 \mathrm{kPa}$ as described by Walker et al. (2009).

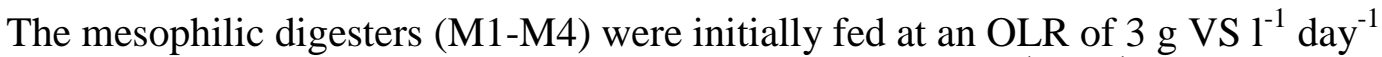
which was then steadily raised to the target OLR of $4 \mathrm{~g} \mathrm{VS}^{-1}$ day $^{-1}$ by day 34 in M1\&2, and $5 \mathrm{~g} \mathrm{VS}^{-1}$ day $^{-1}$ by day 62 in M3\&4. The thermophilic digesters (T1-T4) were acclimated by raising the inoculum temperature from $35^{\circ} \mathrm{C}$ to $55^{\circ} \mathrm{C}$ in one step and then not feeding for 12 days. After this the OLR was steadily increased from $0.5 \mathrm{~g} \mathrm{VS} \mathrm{l}^{-}$ ${ }^{1}$ day $^{-1}$ to $4 \mathrm{~g} \mathrm{VS}^{-1}$ day $^{-1}$ by day 120 in $\mathrm{T} 1 \& 2$, and to $5 \mathrm{~g} \mathrm{VS}^{-1}$ day $^{-1}$ by day 150 in T3\&4. Digesters were then operated for at least 3 hydraulic retention times (HRT), with one HRT being equal to 68.5 and 54.8 days at OLR 4 and $5 \mathrm{~g} \mathrm{VS} \mathrm{l}^{-1}$ day $^{-1}$, respectively.

Each digester received trace element (TE) supplementation based on the amount of feedstock added to maintain a cation concentration (in addition to that naturally present from the feedstock) of $10 \mathrm{mg} \mathrm{l}^{-1} \mathrm{Fe}\left(\right.$ as $\left.\mathrm{FeCl}_{2} \cdot 4 \mathrm{H}_{2} \mathrm{O}\right) ; 1 \mathrm{mg} \mathrm{l}^{-1}$ of $\mathrm{Co}\left(\mathrm{CoCl}_{2} \cdot 6 \mathrm{H}_{2} \mathrm{O}\right), \mathrm{Mn}$ $\left(\mathrm{MnCl}_{2} \cdot 4 \mathrm{H}_{2} \mathrm{O}\right), \mathrm{Ni}\left(\mathrm{NiCl}_{2} \cdot 6 \mathrm{H}_{2} \mathrm{O}\right), \mathrm{Zn}\left(\mathrm{ZnCl}_{2}\right)$; and $0.1 \mathrm{mg} \mathrm{l} \mathrm{l}^{-1}$ of $\mathrm{Cu}\left(\mathrm{CuCl}_{2} \cdot \mathrm{H}_{2} \mathrm{O}\right), \mathrm{B}$ $\left(\mathrm{H}_{3} \mathrm{BO}_{3}\right)$ and $\mathrm{Al}\left(\mathrm{AlCl}_{3} \cdot 6 \mathrm{H}_{2} \mathrm{O}\right)$. Likewise, oxyanions concentrations were maintained at a minimum of $0.1 \mathrm{mg} \mathrm{l}^{-1}$ of $\mathrm{Mo}$ (as $\left.\left(\mathrm{NH}_{4}\right)_{6} \mathrm{Mo}_{7} \mathrm{O}_{24} \cdot 4 \mathrm{H}_{2} \mathrm{O}\right)$, Se $\left(\mathrm{Na}_{2} \mathrm{SeO}_{3}\right)$ and $\mathrm{W}$ $\left(\mathrm{Na}_{2} \mathrm{WO}_{4} \cdot 2 \mathrm{H}_{2} \mathrm{O}\right)$. The TE supplementation was based on a preliminary version of that recommended by Banks et al. (2012). In both cases the TE were supplied by weekly addition of concentrated solutions of these two mixes. 


\subsection{Analytical methods}

Total and volatile solids (TS and VS) contents were determined according to Standard Method $2540 \mathrm{G}$ (APHA, 2005). pH was measured using a combination glass electrode calibrated in buffers at $\mathrm{pH} \mathrm{4,7}$ and 9. Alkalinity was measured by titration with $0.25 \mathrm{~N}$ $\mathrm{H}_{2} \mathrm{SO}_{4}$ to endpoints of $\mathrm{pH} 5.7$ and 4.3, to allow determination of total (TA), partial (PA) and intermediate alkalinity (IA) (Ripley et al., 1986). Total Kjeldahl nitrogen (TKN) was determined after acid digestion (sulphuric acid) using a block digestion system, with ammonia determined using a steam distillation unit according to the manufacturer's instructions (Buchi, UK). Volatile fatty acids (VFA) were quantified in a Shimazdu GC2010 gas chromatograph (Shimadzu, Milton Keynes, UK), using a flame ionization detector and a capillary column type SGE BP-21. Samples were acidified to $10 \%$ using formic acid and measured against mixed standards of 50,250 and $500 \mathrm{mg} \mathrm{l}^{-1}$ of acetic, propionic, iso-butyric, n-butyric, iso-valeric, valeric, hexanoic and heptanoic acids (APHA, 2005). Biogas composition $\left(\mathrm{CH}_{4}\right.$ and $\left.\mathrm{CO}_{2}\right)$ was determined using a Varian star $3400 \mathrm{CX}$ Gas Chromatograph with a gas standard of $65 \% \mathrm{CH}_{4}$ and $35 \%(\mathrm{v} / \mathrm{v}) \mathrm{CO}_{2}$. TS and VS destruction was calculated on a weekly basis by mass balance. For this purpose it was assumed that the wet weight of digestate removed was equal to that of feedstock added, minus the weight of biogas removed. The weight of biogas removed was estimated from the weekly average volume and gas composition in terms of $\% \mathrm{CH}_{4}$ and $\mathrm{CO}_{2}$ (ignoring water vapour and other gases).

Further characterisation was carried out on samples prepared by air drying to constant weight and then milled to a particle size $\leq 0.5 \mathrm{~mm}$ in a micro-hammer mill (Retsch, Germany). Calorific values (CV) were determined using a bomb calorimeter (CAL2kECO, South Africa). Elemental composition $(\mathrm{C}, \mathrm{H}, \mathrm{N})$ content was determined using a FlashEA 1112 Elemental Analyzer, (Thermo Finnigan, Italy) based on the manufacturer's instructions using methionine, L-cystine and sulphanilamide as standards. Neutral detergent fibre (NDF), Acid detergent fibre (ADF) and Acid detergent lignin (ADL) were analysed using the FiberCap ${ }^{\mathrm{TM}}$ system (FOSS Analytical $\mathrm{AB}$, Sweden). Inorganic elements were extracted in nitric acid and the extract filtered and diluted to $50 \mathrm{ml}$ with deionised water (Milli-Q Gradient, Millipore, Watford, UK). Phosphorus was measured by the ammonium molybdate spectrometric method (ISO 6878: 2004). Samples for trace element determination (Co, Fe, Ni, Mo, Se) were sent to an external laboratory for analysis by ICP-MS (Severn Trent Laboratory Limited, UK).

Theoretical CV was calculated using the Du Long equation according to the method in Combustion File 24 (IFRF, 2013) based on the elemental composition and assuming $0.5 \% \mathrm{~S}$ content.

Dewaterability was measured by capillary suction time (CST) and frozen image centrifugation (FIC). The CST test was carried out using a Triton-WRPL type 319 apparatus and paper (Triton Electronics Ltd, UK). FIC testing was performed using a Triton WRC model I6I centrifuge (Triton Electronics Ltd, UK) at maximum speed (equivalent to $100 \mathrm{~g}$ ), with supernatant height recorded against time. Foaming was measured using the aeration foaming potential test (Zabranska et al., 2002), in which $100 \mathrm{ml}$ of digestate was sparged with an air flow rate of $11 \mathrm{~min}^{-1}$ for 5 minutes. The foam height was then recorded every minute for $33 \mathrm{~min}$ or until the foam subsided, and the result calculated using Eq. (1). Foaming tendency, foam stability and foaming 
propensity were calculated based on Ganidi et al. (2011) and Zabranska et al. (2002), as shown in Eqs. (2)-(4):

$$
\begin{aligned}
& \text { Foaming Potential }=\frac{\text { foam volume after } 33 \text { minutes }(\mathrm{ml})}{\text { digestate volume }(\mathrm{ml})} \\
& \text { Foaming Tendency }=\frac{\text { foam volume produced }(\mathrm{ml})}{\text { air flow rate }\left(\mathrm{ml} \mathrm{min}{ }^{-1}\right)} \\
& \text { Foam Stability }=\frac{\text { foam volume after } 33 \text { minutes }(\mathrm{ml})}{\text { air flow rate }\left(\mathrm{ml} \mathrm{min}{ }^{-1}\right)} \\
& \text { Foaming Propensity }=\frac{\text { level of foam volume after aeration }(\mathrm{mm})}{\text { weight of digestate }(\mathrm{g} \mathrm{TS})}
\end{aligned}
$$

Scanning electron microscopy (SEM) with FEI Quanta 200 SEM was used to characterise the structure of the digestate and of non-cellular light fraction samples. The procedures for SEM's sample preparation was as follows: samples were placed into fixative solution (3\% glutaraldehyde and $4 \%$ formaldehyde in 0.1 M PIPES buffer $\mathrm{pH}$ 7.2) to preserve and maintain their original structure. The samples were then rinsed twice in buffer solution (0.1 M PIPES) first for $1 \mathrm{~h}$ and then for $10 \mathrm{~min}$. This was then followed by multiple rinses in ethanol solution in the following order: $30 \%, 50 \%, 70 \%$, 95\% and absolute ethanol for $10 \mathrm{~min}$ in each solution. After that, the last rinsing procedure was in absolute ethanol solution for $20 \mathrm{~min}$. The samples were dried using a critical point drier (Balzers - CPD 030) for $20 \mathrm{~min}$ in order to preserve the initial structure of the specimen without damage to the cell structure. The specimens were then placed on stubs and coated using a sputter coater (SEM coating unit E 5100 Polaron equipment limited) for 5 min followed by mounting on aluminium stubs which were coated with gold palladium.

\section{Results and discussions}

\subsection{Feedstock characteristics}

The characteristics of the SBP pulp are shown in Table 1. As expected it had a high moisture content of around $76 \%$, with VS comprising $93 \%$ of TS. Trace element concentrations were very low, confirming the need for supplementation (Demirel and Scherer, 2011). The $\mathrm{C} / \mathrm{N}$ value was favourable for digestion at $\sim 25$ on a TS basis, with most of the carbon available as either cellulose or hemicellulose. The measured calorific value of $16.8 \mathrm{MJ} \mathrm{kg}^{-1} \mathrm{TS}$ was in good agreement with the theoretical value based on elemental composition of $16.1 \mathrm{MJ} \mathrm{kg}^{-1} \mathrm{TS}$, supporting the validity of the analytical results.

\subsection{Digestion performance}

Table 2 shows key parameters for mesophilic and thermophilic digestion, taken as average values over a 30-day period at the end of $3 \mathrm{HRT}$. In mesophilic AD, the digesters fed at an OLR of $4 \mathrm{~g} \mathrm{VS}^{-1}$ day $^{-1}$ had a specific biogas production (SBP) and specific methane production (SMP) of $0.554 \mathrm{~g}^{-1} \mathrm{VS} \mathrm{day}^{-1}$ and $0.292 \mathrm{CH}_{4} \mathrm{~g}^{-1} \mathrm{VS}$ day $^{-1}$, 
respectively. In digester M4 the SBP at an OLR of $5 \mathrm{~g} \mathrm{VS}^{-1}$ day $^{-1}$ was lower at 0.5491 $\mathrm{g}^{-1} \mathrm{VS} \mathrm{day}^{-1}$, with a corresponding fall in SMP to $0.2831 \mathrm{CH}_{4} \mathrm{~g}^{-1} \mathrm{VS} \mathrm{day}^{-1}$; gas production in digester M3 was lost from around day 230 (Fig. 2a and c). These results suggest that in mesophilic conditions the conversion process is becoming limiting at the higher loading. Operating at the higher OLR, however, gave an increase in volumetric

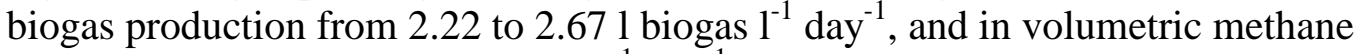
production from 1.17 to $1.38 \mathrm{C} \mathrm{CH}_{4} \mathrm{l}^{-1}$ day $^{-1}$. If stable operation can be maintained the higher loading may be preferable in economic terms, despite the small loss in conversion yield.

In thermophilic $\mathrm{AD}$ the specific biogas production at both OLR 4 and $5 \mathrm{~g} \mathrm{VS}^{-1} \mathrm{day}^{-1}$ was higher than in mesophilic $\mathrm{AD}$, with an average of $0.664 \mathrm{Ig}^{-1} \mathrm{VS}_{\text {day }}^{-1}$ and $0.681 \mathrm{~g} \mathrm{~g}^{-}$ ${ }^{1} \mathrm{VS}_{\text {day }}{ }^{-1}$, respectively (Fig. $2 \mathrm{~b}$ and d). A similar improvement compared to the mesophilic system was seen in specific methane production (SMP), and this also increased from $0.3451 \mathrm{CH}_{4} \mathrm{~g}^{-1} \mathrm{VS} \mathrm{day}^{-1}$ at OLR $4 \mathrm{~g} \mathrm{VS} \mathrm{l}^{-1}$ day $^{-1}$ to $0.355 \mathrm{l} \mathrm{CH}_{4} \mathrm{~g}^{-1} \mathrm{VS}$ day $^{-1}$ at OLR $5 \mathrm{~g} \mathrm{VS} \mathrm{l}^{-1}$ day $^{-1}$. The results indicate that the thermophilic process can produce a higher conversion yield than mesophilic, and that this is sustainable even at the higher loading. This supports the work of Ferrer et al. (2010) who found that in thermophilic AD the increase in volumetric methane production rate remained linear with increasing OLR. The energy value of the methane recovered in thermophilic AD was 12.36 and $12.72 \mathrm{MJ} \mathrm{kg}^{-1} \mathrm{VS}$ based on a conversion factor of $35.82 \mathrm{MJ} \mathrm{m}^{-3}$, equivalent to $68.1 \%$ and $70.1 \%$ of the measured calorific value of the substrate.

Under mesophilic conditions total alkalinity and total ammonia nitrogen (TAN) increased with time (Fig. 3a). At an OLR of $4 \mathrm{~g} \mathrm{VS}^{-1}$ day $^{-1}$ the alkalinity rose from $~ 9$ g $\mathrm{CaCO}_{3} \mathrm{~kg}^{-1}$ wet weight (WW) to $16-17 \mathrm{~g} \mathrm{CaCO}_{3} \mathrm{~kg}^{-1} \mathrm{WW}$ by the end of the experiment. This corresponded to an increase in TAN (Fig. 3b) which reached 1.4-1.5 g $\mathrm{N} \mathrm{kg}^{-1} \mathrm{WW}$, below values considered inhibitory to mesophilic (Yenigün and Demirel, 2013). At an OLR of $5 \mathrm{~g} \mathrm{VS}^{-1}$ day $^{-1}$ total alkalinity and TAN concentrations decreased from around day 120. This was followed by a decrease in pH (Fig. 3c), which then fell sharply in M3 from day 224, corresponding to the loss in methane production (Fig. 2c). The fall in $\mathrm{pH}$ was reflected in the IA/PA ratio which rose from $\sim 0.35$ to $\sim 0.7$ at OLR 5 $\mathrm{g} \mathrm{VS}^{-1}$ day $^{-1}$ (Fig. 3d). This was probably as a result of the reduced TAN concentration at the higher OLR, which could have been due to reduced protein hydrolysis due to the shortened HRT.

In thermophilic conditions TAN and alkalinity both showed a gradual increase over time at both OLRs tested, with similar values of $16-17 \mathrm{~g} \mathrm{CaCO}_{3} \mathrm{~kg}^{-1} \mathrm{WW}$ and around 1.9-2.0 $\mathrm{g} \mathrm{N} \mathrm{kg}^{-1} \mathrm{WW}$ at the end of the experimental period (Fig. 3a and b). The ratio of intermediate to partial alkalinity (IA/PA) for all digesters under thermophilic conditions was 0.32 , very close to the value of 0.3 suggested by Ripley et al. (1986) as indicating good process stability. $\mathrm{pH}$ remained stable at around 7.7 (Fig. 3c). The slightly higher TAN concentrations found under thermophilic conditions support the view that greater protein hydrolysis was occurring. Final TAN values were still below inhibitory concentrations, as stated by Yenigün and Demirel (2013), and probably provided additional buffering capacity. 
In mesophilic AD the total VFA concentration showed minor fluctuations during transitional increases in OLR, but under steady state conditions at OLR $4 \mathrm{~g} \mathrm{VS} \mathrm{l}^{-1}$ day $^{-1}$ VFA remained below $100 \mathrm{mg} \mathrm{l}^{-1}$. At OLR $5 \mathrm{~g} \mathrm{VS} \mathrm{l}^{-1} \mathrm{day}^{-1}$ the VFA concentration rose sharply after day 217 in both digesters (Fig. 3e), contributing to an increase in IA/PA ratio. In digester $\mathrm{M} 3$ the $\mathrm{pH}$ fell below 6.7 by day 231, at which point methanogenesis failed; while the VFA concentration continued to rise, reaching $22 \mathrm{~g} \mathrm{l}^{-1}$ by day 259 . In digester M4 the increase in VFA was less severe and the $\mathrm{pH}$ did not fall below 7.0, allowing methanogenic activity to continue; although instability was apparent the digester did not fail. In thermophilic conditions the total VFA concentration was high during the acclimatisation period but fell to less than $250 \mathrm{mg} \mathrm{l}^{-1}$ by day 71 (Fig. 3f). There was then a gradual rise at both OLR to average values between 500-800 $\mathrm{mg} \mathrm{l}^{-1}$. This is consistent with other reports that indicate VFA concentrations in thermophilic digesters are higher than in comparable mesophilic digesters (de la Rubia et al., 2006).

Under mesophilic AD, VS destruction decreased with an increase in OLR with average values of $85 \%$ and $77 \%$ for OLR 4 and $5 \mathrm{~g} \mathrm{VS}^{-1}$ day $^{-1}$, respectively (Fig. $3 \mathrm{~g}$ and h). In thermophilic AD, however, the average VS destruction at both loadings was $88 \%$. The higher VS destruction supports the small increase in biogas and methane productions previously noted.

The above results indicate that thermophilic AD is better suited to the digestion of SBP compared to mesophilic AD, based on the better performance and improved stability especially at the higher loading.

\subsection{Dewaterability characteristics}

The dewaterability characteristics of digestate from mesophilic and thermophilic AD are shown in Fig. 4. Weekly measurements of the capillary suction time (CST) showed that filterability of the mesophilic digestate deteriorated over the period of 3 HRT (Fig. 4a). More specifically, at an OLR of $4 \mathrm{~g} \mathrm{VS} \mathrm{l}^{-1}$ day $^{-1}$ the CST time gradually increased from $369 \mathrm{~s}$ to $6000 \mathrm{~s}$ by the end of 1 HRT (day 69) and reached a value of $\sim 11000 \mathrm{~s}$ after 147 days. This was followed by a further sharp increase to more than $\sim 70000 \mathrm{~s}$ by day 207 ( 3 HRT), reaching the maximum value of over $84000 \mathrm{~s}(>24 \mathrm{~h}$ ) by day 225 . A similar but slightly more severe result was seen at the higher loading rate with an earlier onset of the sharp changes, presumably as a result of the shorter HRT. After 3 HRT the CST value at the higher loading was again more than $24 \mathrm{~h}$. These extremely high CST values are usually interpreted to mean that the water is strongly bound to the digestate, and other observations supported this as the digestate itself became denser and thicker making it very difficult to filter. As neither filtration nor CST tests showed any appreciable dewatering, it was thought this could be due to either colloidal solids or high molecular weight extracellular polymers blinding the filter pores. Whichever is the case the digestate could be considered as very hydrophilic with the water apparently strongly bound between discrete particles (Colin and Gazbar, 1995).

Digestate from the thermophilic digesters showed better dewaterability: at both of the OLR tested there was no obvious difference in dewaterability measured by CST, which remained in the range of 5000 - 6000 s over the entire period of 3 HRT (165 and 207 days for each OLR, respectively). 
The FIC test was also able to show a clear difference between the dewaterability of the mesophilic and thermophilic digestates (Fig. 4b). Initially (day 15 - 155) for digestate from mesophilic AD operated at OLR $4 \mathrm{~g} \mathrm{VS}^{-1}$ day $^{-1}$ approximately $40 \%$ of supernatant liquid could be separated after one hour of centrifugation at $1100 \mathrm{rpm}$ (100 $g$ ). After this time there was a rapid deterioration with $0 \%$ of supernatant liquid separation by day 225. At OLR $5 \mathrm{~g} \mathrm{VS} \mathrm{l}^{-1}$ day $^{-1}$ there was a more gradual deterioration which started earlier, so that the $\sim 50 \%$ of supernatant liquid that could be separated initially had decreased to $20 \%$ at the end of 1 HRT (day 55) and $0 \%$ separation occurred shortly after 2 HRT had been reached (day 148).

Dewaterability of thermophilic digestate showed a small improvement with time as measured by the FIC test, although there was a slight fluctuation towards the end of 3 HRT. All the samples together gave an average of $80 \%$ supernatant liquid separation after one hour of centrifugation at $100 \mathrm{~g}$. The above result suggests that dewatering may be possible without chemical destabilisation of the digestate matrix to reduce hydrophobicity, although this approach might also lead to further improvements (not tested here).

It can be concluded that the digestion of SBP under thermophilic conditions improved the digestate dewaterability, that the digestate floc structure remained unaltered over prolonged digestion periods, and that it is a good option to pursue when the other benefits are also considered. The findings from this study are in good agreement with Chi et al. (2010) who showed that thermophilic AD improved the dewaterability of digested activated sludge.

\subsection{Digester Foaming}

Another problem encountered in the mesophilic AD of SBP is the appearance of stable foam, in particular at high OLR (Suhartini et al., 2011). In the experiments reported, foam appeared in the mesophilic digesters several weeks before the end of the experimental period and caused some operational problems. Foaming was more severe at the higher OLR: at OLR $5 \mathrm{~g} \mathrm{VS}^{-1}$ day $^{-1}$ noticeable foaming occurred in duplicate digesters on day 179 and day 183, then continuously worsened up to the end of 3 HRT (day 227). The foaming resulted in gas tube blockages which could lead to an increase in pressure in the digester, eventually 'blowing out' the feed bung accompanied by some escape of digestate. This occurred in digester M3 on day 186 and 209 and, despite adjustment of the quantity of daily feed to the reduced working volume, was linked to some instability as seen in the increase in total VFA concentration and decline in $\mathrm{pH}$ value (Fig. 3). Similar trends were also seen in the duplicate mesophilic digesters operating at OLR $4 \mathrm{~g} \mathrm{VS}^{-1}$ day $^{-1}$, where foam first appeared on day 187 and day 192 and persisted until 3 HRT (day 241). After this foam control in the digesters was attempted using antifoam which proved to be effective, but only over short periods after which the problem recurred. No obvious signs of foaming were seen in the thermophilic digesters over the full operational period of 3 HRT. Stoppok and Buchholz (1985) also observed foaming in SBP digesters under mesophilic conditions, which was attributed to the high viscosity of the fluid-substrate mixture and the high cellulosic composition of SBP. More recently, Brooks et al. (2008) observed foaming at loading rates above 5.5 $\mathrm{kg} \mathrm{COD} \mathrm{m}^{-3}$ day $^{-1}$ (laboratory scale) and $10 \mathrm{~kg} \mathrm{COD} \mathrm{m}^{-3}$ day $^{-1}$ (pilot scale), and attributed this to the high sugar content of fresh SBP. This result supports the findings 
of Zabranska et al. (2002) who also observed that thermophilic AD was more resistant to foaming problems than mesophilic $\mathrm{AD}$ when sewage sludge was the feedstock.

Figure 5 shows the results of the foaming potential test over time for the digesters operated under mesophilic and thermophilic conditions. The samples from mesophilic $\mathrm{AD}$ at OLR 4 and $5 \mathrm{~g} \mathrm{VS}^{-1}$ day $^{-1}$ both showed foaming potential, but with a final value of 0.14 at the higher OLR compared to 0.10 for the lower OLR (Fig. 5a). The foaming tendency showed a gradual increase over the experimental period, from $\sim 0.01$ to 0.04 $\mathrm{ml} \mathrm{ml}^{-1} \mathrm{~min}^{-1}$ at OLR $4 \mathrm{~g} \mathrm{VS}^{-1} \mathrm{day}^{-1}$, and from $\sim 0.02$ to $0.06 \mathrm{ml} \mathrm{ml}^{-1} \mathrm{~min}^{-1}$ at OLR $5 \mathrm{~g}$ $\mathrm{VS}^{-1}$ day $^{-1}$ (Fig. 5b). A similar trend was seen in foam stability which increased to 0.03 $\mathrm{ml} \mathrm{ml}^{-1} \mathrm{~min}^{-1}$ and $0.04 \mathrm{ml} \mathrm{ml}^{-1} \mathrm{~min}^{-1}$ at OLR of 4 and $5 \mathrm{~g} \mathrm{VS} \mathrm{l}^{-1}$ day $^{-1}$ respectively by the end of 3 HRTs (Fig. 5c). There was a slight decrease in foaming propensity over the period of $3 \mathrm{HRT}$, with final values of $0.95 \mathrm{~mm} \mathrm{~g}^{-1} \mathrm{TS}$ and $1.42 \mathrm{~mm} \mathrm{~g}^{-1} \mathrm{TS}$ for OLR 4 and $5 \mathrm{~g} \mathrm{VS}^{-1}$ day $^{-1}$ respectively (Fig. 5d).

Digestate for the thermophilic digesters gave values of zero in the foaming potential test, and as any foam that did form during the 5-min aeration had disappeared within one minute after aeration stopped, all of the other foaming tests were also negative. This result agreed with the visual observations of the digester contents described above. In conclusion it can be stated that thermophilic AD largely eliminates the foaming problems that occur in mesophilic AD of SBP.

\subsection{Digestate component parts}

Centrifugation tests showed that mesophilic digestate separated into four parts: a solid residue, biomass layer, non-cellular light fraction, and supernatant liquid (Fig. S1a). The non-cellular light fraction consisted of a high molecular weight material which could potentially be made up of extracellular polymer substances (EPS) or soluble microbial products (SMP). Thermophilic digestate, however, showed little or no non-cellular light fraction material. This observation could be interpreted as indicating that this component is responsible for the poor dewaterability and foaming in the mesophilic digesters. EPS has been reported on a number of occasions (Mikkelsen and Keiding, 2002; Ramesh et al., 2006; Zhen et al., 2012) and has been variously described as being composed of proteins, carbohydrate (polysaccharide), lipids, and humic acid. SMP on the other hand are secreted by cells as soluble components: they contain less polysaccharide and no proteins, but have roughly the same amount of lipid and more humic substances compared with soluble EPS (Ramesh et al., 2006). Characterisation of this high molecular weight material showed that the major component (43.4\%) was likely to be a protein, while the polysaccharide content was $8.3 \%$, suggesting that it was best classified as EPS (Table 3).

To test whether the EPS might be heat labile and therefore broken down in thermophilic digesters, as opposed to not being produced, a further experiment was carried out. This compared the CST and FIC values of mesophilic digestate before and after heating to 55 ${ }^{\circ} \mathrm{C}, 60{ }^{\circ} \mathrm{C}$ and $65{ }^{\circ} \mathrm{C}$. The result showed that increasing the temperature made no significant difference to the CST or FIC values or to the amount of non-cellular light fraction that could be recovered through centrifugation. This indicated that the material was thermally stable at the temperatures tested, suggesting that the EPS was not produced in the thermophilic process, rather than being produced and then subsequently 
broken down. Barjenbruch and Kopplow (2003) showed that EPS in wastewater sludges could be broken down by autoclaving at $121{ }^{\circ} \mathrm{C}$ and that this led to a reduction in foaming during digestion, but heat treatments at lower temperatures were ineffective.

\subsection{Scanning Electron Microscopy}

SEM analysis was performed to elucidate the morphology and microstructure of digestate samples from mesophilic and thermophilic digesters. Fig. S2a and b show that mesophilic digestate at both OLR tested had an open porous structure, suggesting that water could be held within this sponge-like matrix. In contrast thermophilic digestate had a fine dense appearance without pores (Fig. S2c and d), a structure less likely to retain water. This difference in structure may be responsible for the difference in dewatering characteristics. Fig. S1b shows an SEM image of the extracted non-cellular light fraction which appears as a continuous folded sheet of smooth material.

\section{Conclusions}

Thermophilic digestion of SBP showed performance advantages over mesophilic, including higher specific methane production and enhanced buffering capacity with lower IA/PA ratios. The most important finding was the reduced foaming and improved dewaterability of thermophilic digestates. This was because thermophilic conditions did not lead to the formation of a protein-rich non-cellular light fraction (EPS), probably as a result of better substrate hydrolysis. Mesophilic digestion showed signs of instability at an OLR of $5 \mathrm{~g} \mathrm{VS} \mathrm{I}^{-1} \mathrm{day}^{-1}$. The thermophilic process could operate stably at this OLR and recover more than $68 \%$ of the calorific value as methane.

\section{Acknowledgements}

Thanks are due to the Indonesian Government - Directorate General of Higher Education (DGHE) and the University of Brawijaya - Indonesia for scholarship funding to support this research; and to British Sugar PLC for the supply of materials and good advice.

\section{References}

1. APHA, 2005. Standard Methods for the Examination of Water and Wastewater. American Technical Publisher.

2. Banks, C.J., Zhang, Y., Jiang, Y., Heaven, S., 2012. Trace element requirements for stable food waste digestion at elevated ammonia concentrations. Bioresour. Technol. 104, 127-135.

3. Barber, W.P., 2005. Anaerobic digester foaming: causes and solutions. Water 21, 45-49.

4. Barjenbruch, M., Kopplow, O., 2003. Enzymatic, mechanical and thermal pretreatment of surplus sludge. Adv. Environ. Res. 7, 715-730.

5. British Sugar, 2011. UK Beet Sugar Industry: Sustainability Report 2011. British Sugar plc and NFU Sugar.

6. Brooks, L., Parravicini, V., Svardal, K., Krois, H., Prendi, L., 2008. Biogas from sugar beet press pulp as substitute of fossil fuels in sugar beet factories. Water Sci. Technol. 58, 1497-1504.

7. Brown, S., 2002. Operating a high-rate digester: the southern water experience. Water Environ. 16, 116-120. 
8. Chi, Y.Z., Li, Y.Y., Ji, M., Qiang, H., Deng, H.W., Wu, Y.P., 2010. Mesophilic and thermophilic digestion of thickened waste activated sludge: a comparative study. Adv. Mater. Res. 113-116, 450-458.

9. Colin, F., Gazbar, S., 1995. Distribution of water in sludges in relation to their mechanical dewatering. Water Res. 29, 2000-2005.

10. de la Rubia, M.A., Romero, L.I., Sales, D., Pérez, M., 2006. Pilot-scale anaerobic thermophilic digestor treating municipal sludge. AIChE Journal. 52, 402-407.

11. Demirel, B., Scherer, P., 2011. Review: Trace element requirements of agricultural biogas digester during biological conversion of renewable biomas to methane. Biomass and Bioenergy. 35, 992 - 998.

12. Ferrer, I., Vázquez, F., Font, X., 2010. Long term operation of a thermophilic anaerobic reactor: process stability and efficiency at decreasing sludge retention time. Bioresour. Technol. . 101, 2972-2980.

13. Ganidi, N., S.Tyrrel, Cartmell, E., 2011. The effect of organic loading rate on foam initiation during mesophilic anaerobic digestion of municipal wastewater sludge. Bioresour. Technol. 102, 6637-6643.

14. Ghanem, K.M., El-Refai, A.H., El-Gazaerly, M.A., 1992. Methane production from beet pulp. J. Resour. Convers. Recycl. 6, 267-275.

15. Hutnan, M., Drtil, M., Mrafkova, L., 2000. Anaerobic biodegradation of sugar beet pulp. Biodegrad. 11, 203-211.

16. IFRF, 2013. Online Combustion Handbook ISSN 1607-9116 (Method from Combustion File 24). International Flame Research Foundation, Livorno, Italy. ISSN 1607-9116.Available from: <http://www.handbook.ifrf.net/handbook/> (last accessed November 2013).

17. Koppar, A., Pullammanappallil, P., 2008. Single-stage, batch, leach-bed, thermophilic anaerobic digestion of spend sugar beet pulp. Bioresour. Technol. 99, 2831-2839.

18. Labat, M., Gracia, J.L., Meyer, F., Deschamps, F., 1984. Anaerobic digestion of sugar beet pulps. Biotechnol. Lett. 6, 379-384.

19. Liming, S., Peipei, H.E., Guanghui, Y.U., Pinjing, H.E., 2009. Effect of proteins, polysaccharides, and particle sizes on sludge dewaterability. J. Environ. Sci. 21, 8388.

20. Lovett, D.A., Kavanagh, B.V., Herbert, L.S., 1983. Effect of sludge age and substrate composition on the settling and dewatering characteristic of activated sludge. Water Res. 17, 1511-1515.

21. Massart, N., Bates, R., Neun, G., 2006. The root cause of excessive anaerobic digester foaming. In: Proceedings of the Residual and Biosolids Management Conference. Water Environment Federation, Cincinnati, Ohio, pp. 1099-1117, 1215 March 2006.

22. Medina, A., Jakobsen, I., Vassilev, N., Azcón, R., Larsen, J., 2007. Fermentation of sugar beet waste by Aspergillus niger facilitates growth and $\mathrm{P}$ uptake of external mycelium of mixed populations of arbuscular mycorrhizal fungi. Soil Biol. Biochem. 39, 485-492.

23. Mikkelsen, L.H., Keiding, K., 2002. Physico-chemical characteristics of full scale sewage sludges with implications to dewatering. Water Res. 36, 2451-2462.

24. Pagilla, K.R., Craney, K.C., Kido, W.H., 1997. Causes and effect of foaming in anaerobic sludge digesters. Water Sci. Technol. 26, 463-470. 
25. Parawira, W., Read, J.S., Mattiasson, B., Björnsson, L., 2008. Energy production from agricultural residues: High methane yields in pilot-scale two-stage anaerobic digestion. Biomass Bioenergy. 32, 44-50.

26. Polematidis, I., Koppar, A., Pullammanappallil, P.C., Seaborn, S., Chynoweth, D.P., Teixeira, A.A., Legrand, R., 2007. Biogasification of waste stream and byproducts from sugar beet processing, ASABE Annual International Meeting, Minneapolis Convention Center, Minneapolis, Minnesota, 17-20 June 2007.

27. Ramesh, A., Lee, D.-J., Hong, S.G., 2006. Soluble microbial products (SMP) and soluble extracellular polymeric substances (EPS) from wastewater sludge. Appl.

Microbiol. Biotechnol. 73, 219-225.

28. Ripley, L.E., Boyle, W.C., Converse, J.C., 1986. Improved alkalimetric monitoring for anaerobic digestion of high-strength wastes. J. Water Pollut. Control Fed. 58, 406-411.

29. Speece, R.E., 2008. Anaerobic Biotechnology and Odor/Corrosion Control for Municipalities and Industries. Field Publishing, Inc., Tennessee.

30. Stoppok, E., Buchholz, K., 1985. Continous anaerobic conversion of sugar beet pulp to biogas. Biotechnol. Lett. 7, 119-124.

31. Suhartini, S., Heaven, S., Banks, C.J., 2011. Anaerobic digestion of sugar beet pulp: effects of trace element addition on performance and digestate properties. In: The International Symposium on Anaerobic Digestion of Solid Waste \& Energy Crops, Vienna University of Technology, Vienna, Austria, 28 August - 1 September 2011, pp.1-8.

32. Walker, M., Zhang, Y., Heaven, S., Banks, C., 2009. Potential errors in the quantitative evaluation of biogas production an anaerobic digestion processes. Bioresour. Technol. 100, 6339-6346.

33. Yenigün, O., Demirel, B., 2013. Ammonia inhibition in anaerobic digestion: A review. Process Biochem. 48, 901-911.

34. Yoo, S.D., Harcum, S.W., 1999. Xanthan gum production from waste sugar beet pulp. Bioresour. Technol. 70, 105-109.

35. Zabranska, J., Dohanyos, M., Jenicek, P., Zalpatilkova, P., Kutil, J., 2002. The contribution of thermophilic anaerobic digestion to the stable operation of wastewater sludge treatment. Water Sci. Technol. 46, 447-453.

36. Zhen, G., Lu, X., Li, Y., Zhao, Y., Wang, B., Song, Y., Chai, X., Niu, D., Cao, X., 2012. Novel insights into enhanced dewaterability of waste activated sludge by $\mathrm{Fe}(\mathrm{II})$-activated persulfate oxidation. Bioresour. Technol. 119, 7-14. 


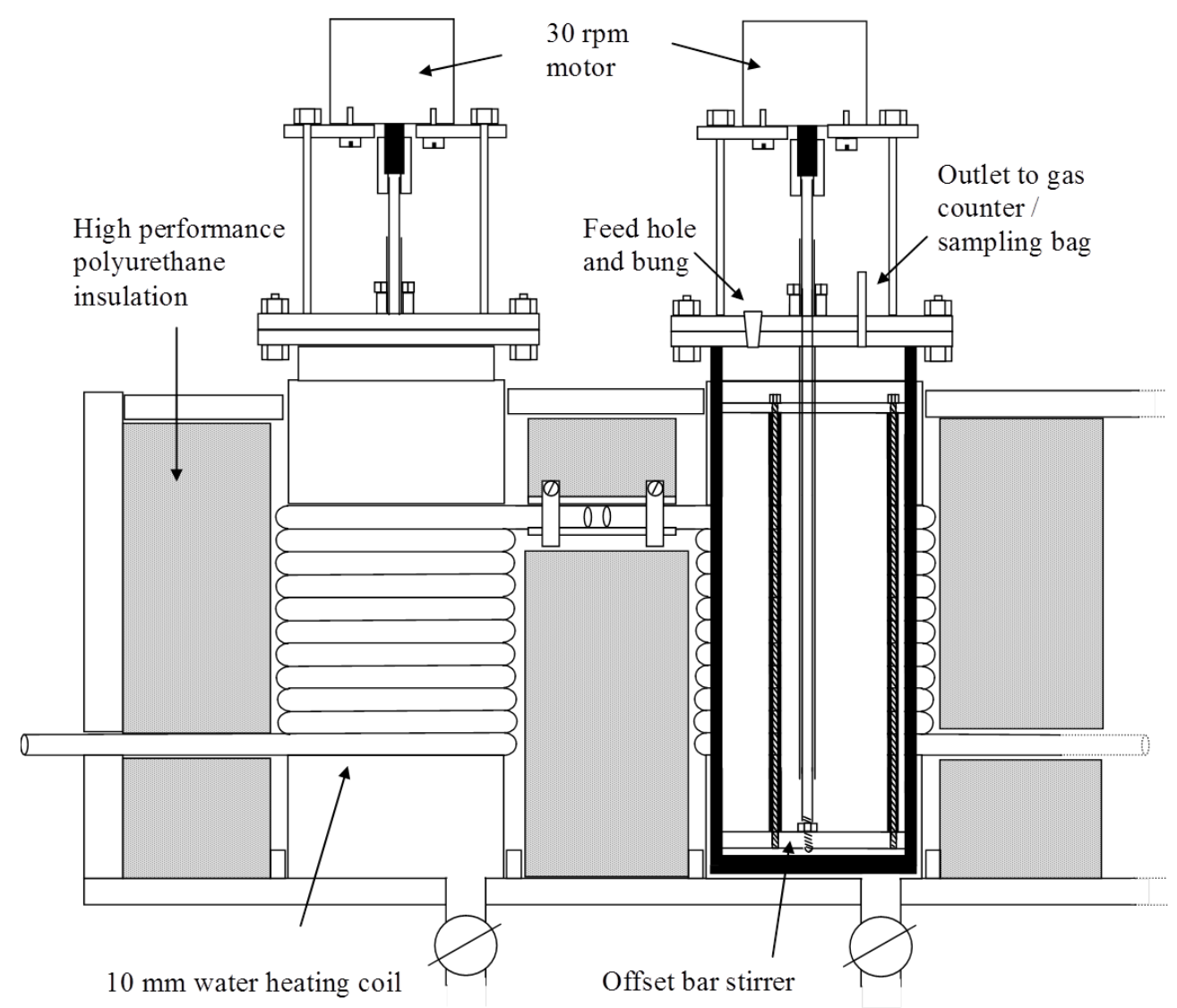

Fig. 1. Model of CSTR anaerobic digester (5-litre) 

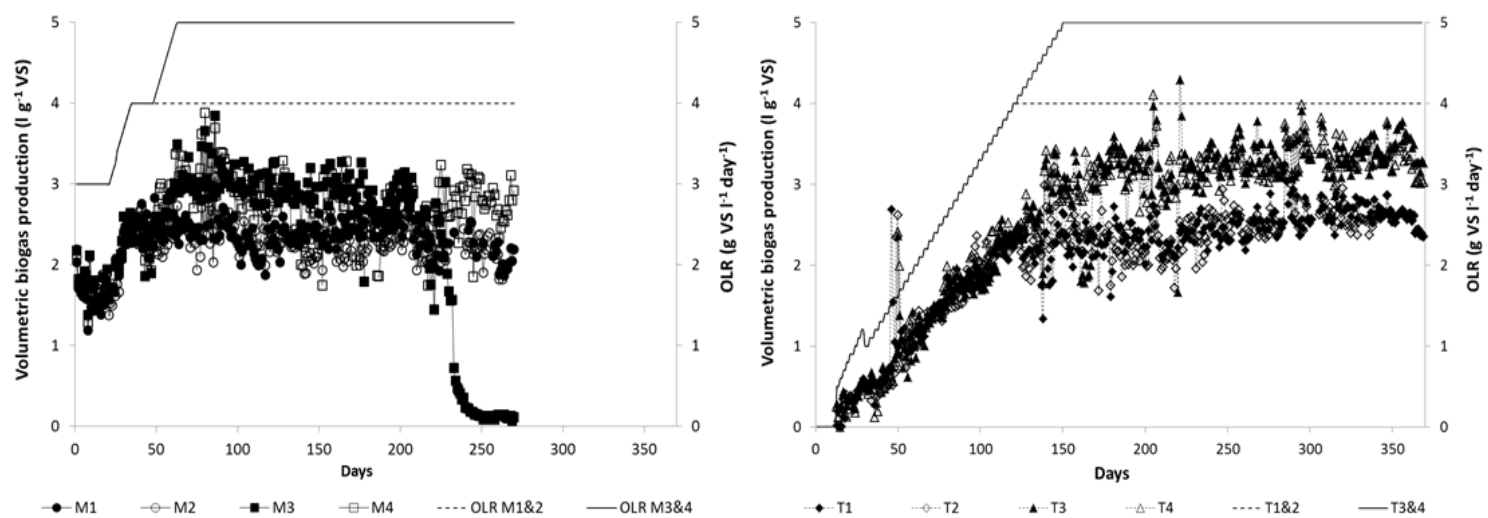

(a)

(b)

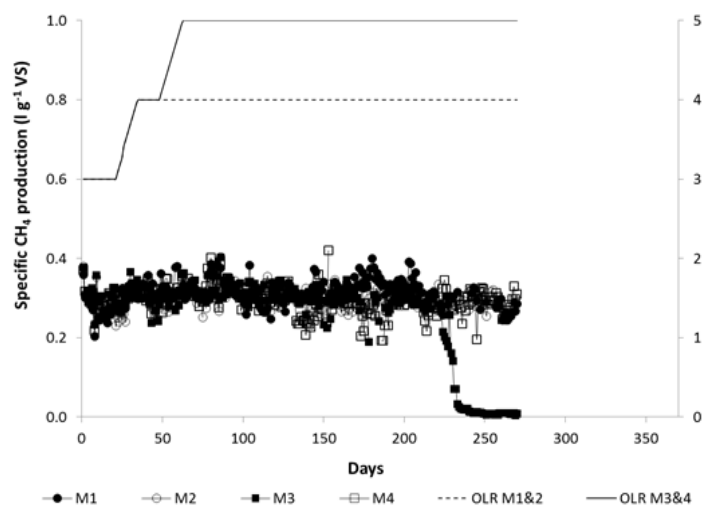

(c)

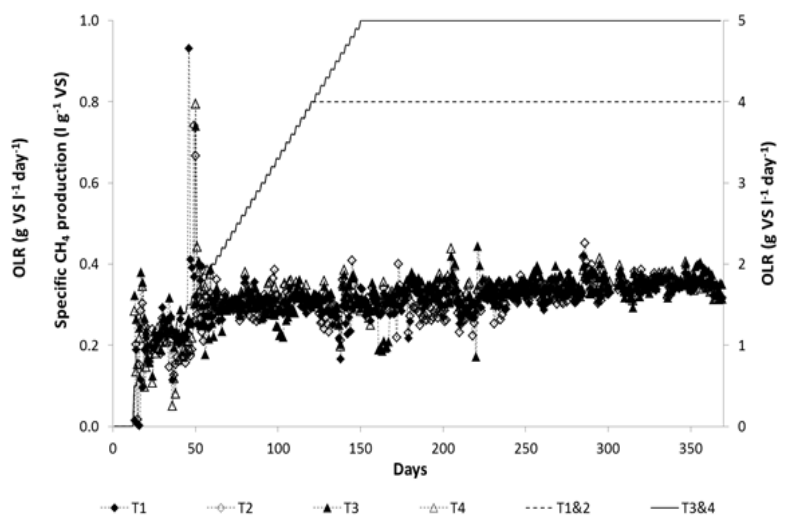

(d)

Fig. 2. Organic loading rate and performance parameters in semi-continuous SBP digestion trials. Volumetric biogas production in (a) mesophilic and (b) thermophilic conditions; specific methane production in (c) mesophilic and (d) thermophilic conditions. 

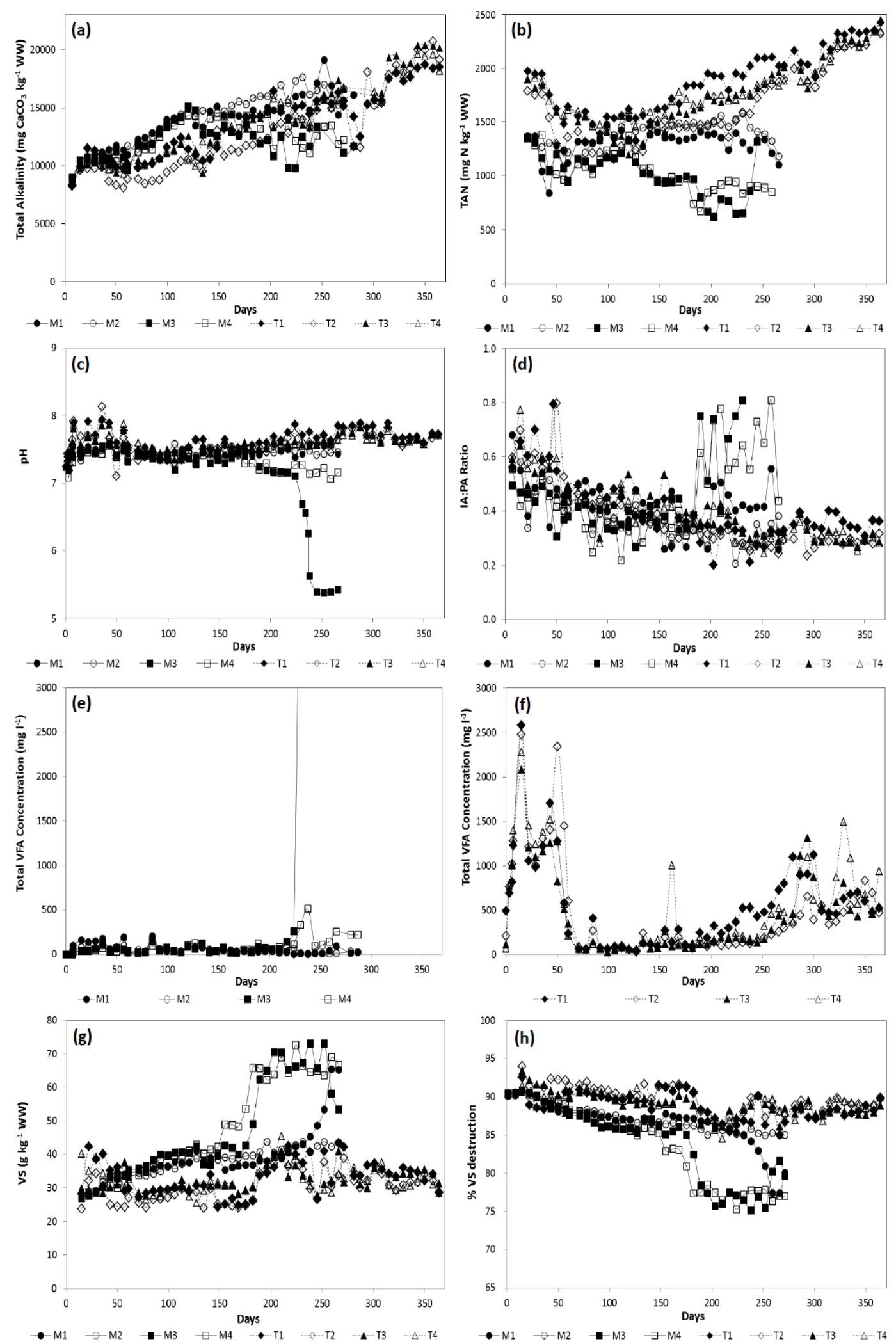

Fig. 3. Process parameters in semi-continuous SBP digestion trials. (a) total alkalinity; (b) total ammonia nitrogen; (c) $\mathrm{pH}$; (d) IA/PA ration; total VFA concentration in (e) mesophilic and (f) thermophilic conditions; (g) VS concentration; (h) VS destruction. 

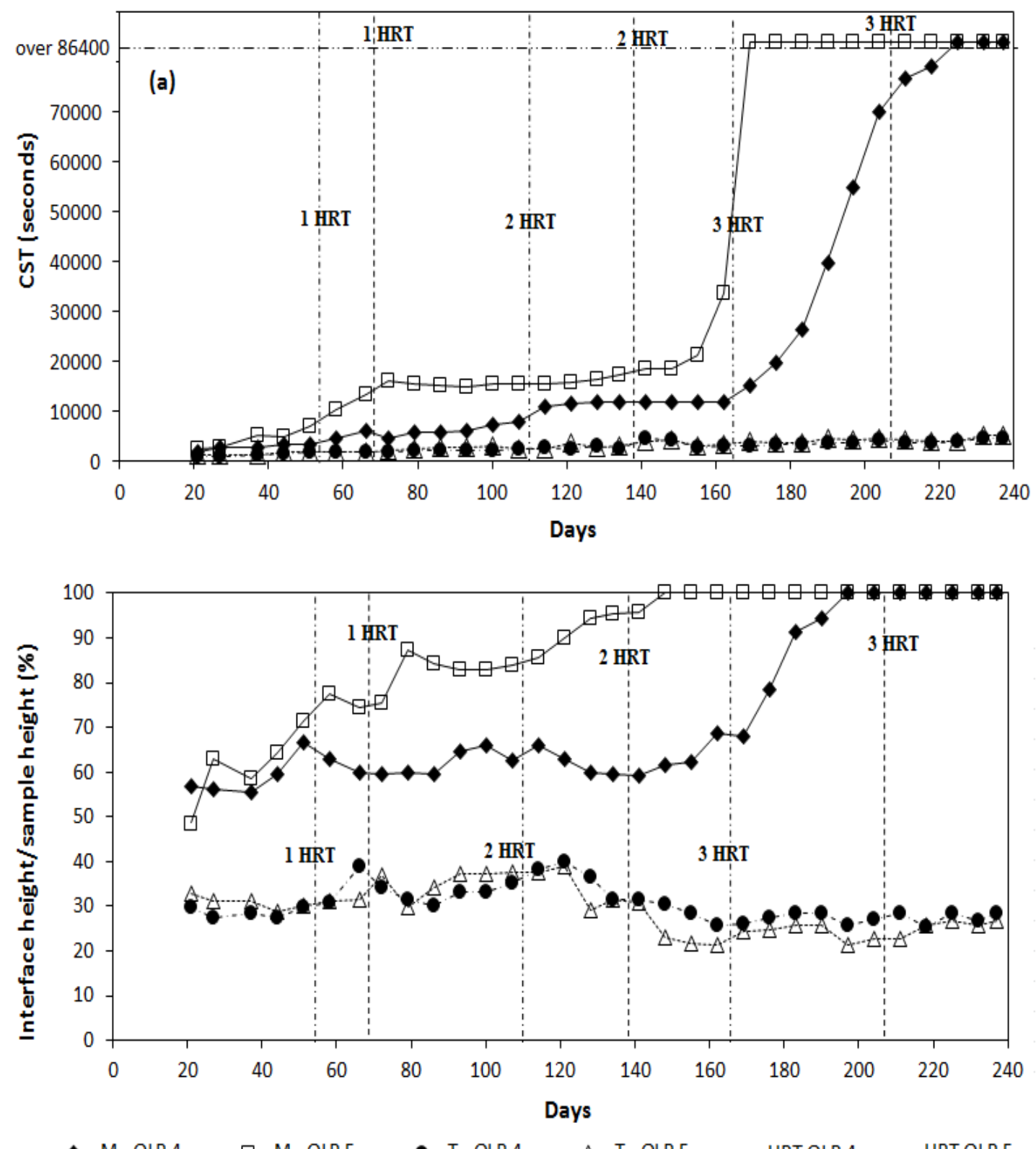

Fig. 4. Results of dewaterability testing on digestates from mesophilic and thermophilic AD of SBP at different OLR. (a) CST time; (b) Supernatant interface height as a \% of original height of SBP digestate during FIC run. Vertical lines indicate completion of one or more HRT at a given loading. 


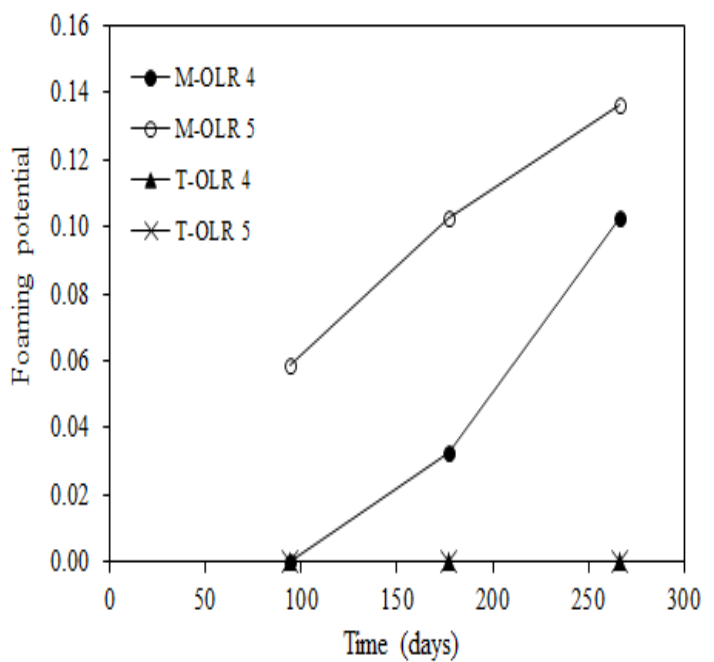

(a)

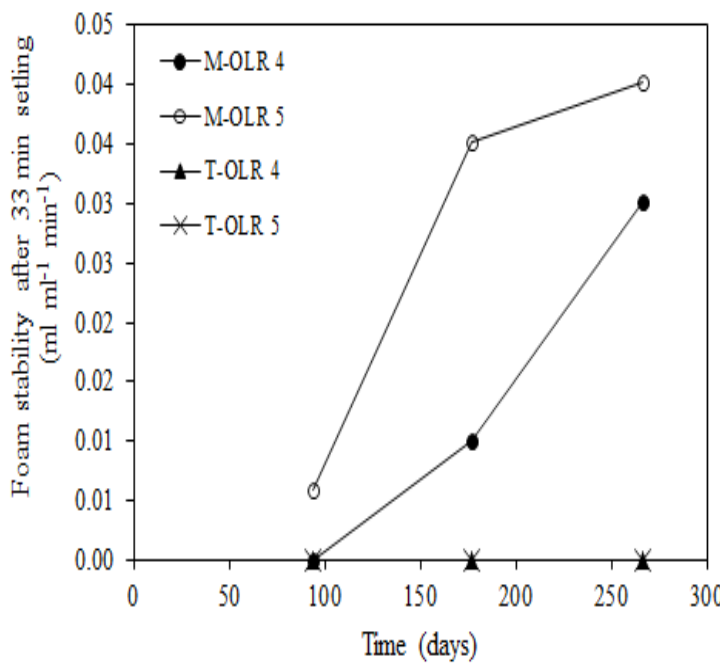

(c)

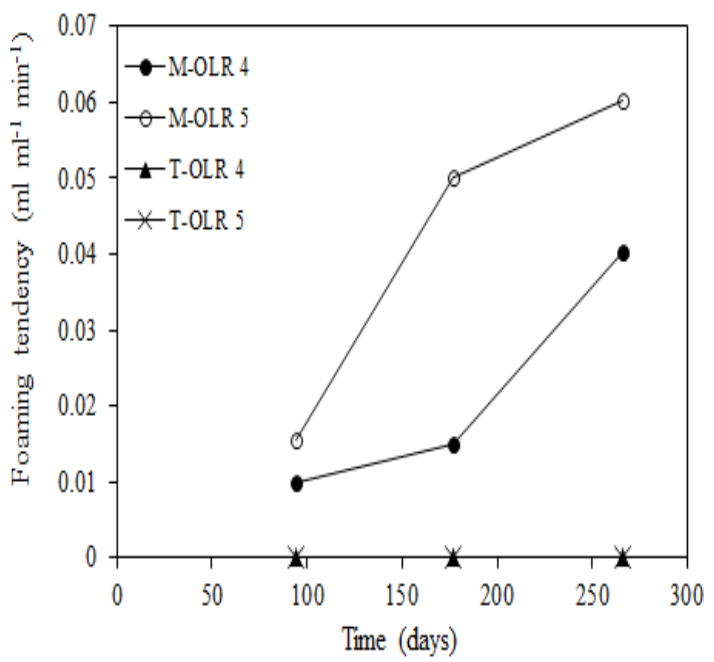

(b)

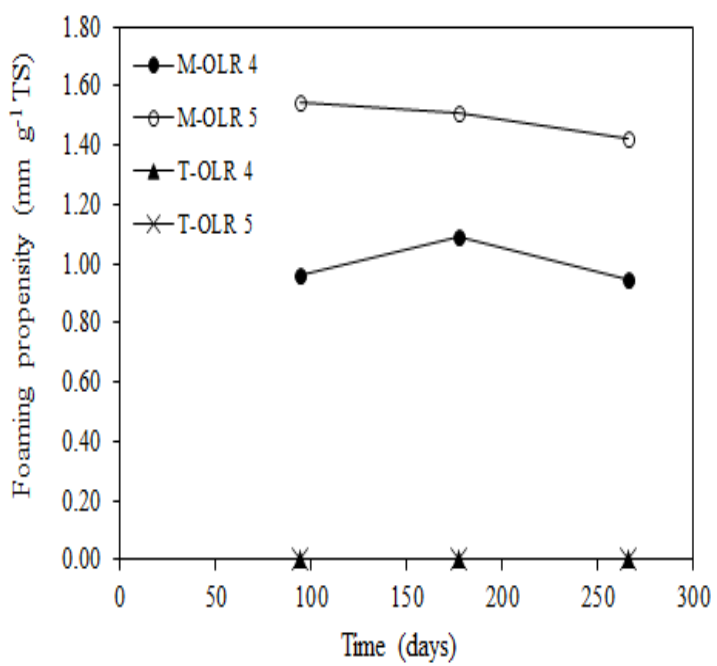

(d)

Fig. 5. Foaming test results for mesophilic and thermophilic SBP digestates: (a) foaming potential; (b) foam stability; (c) foaming tendency; and (d) foaming propensity. 


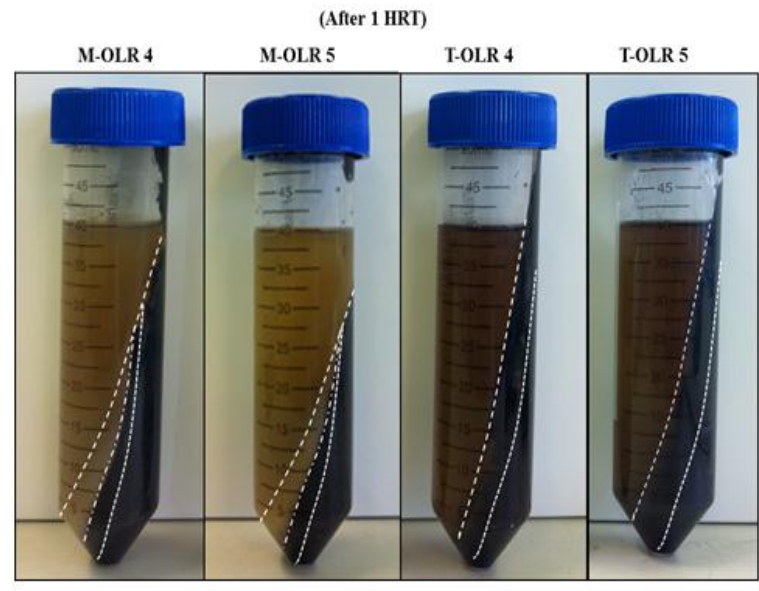

(a)

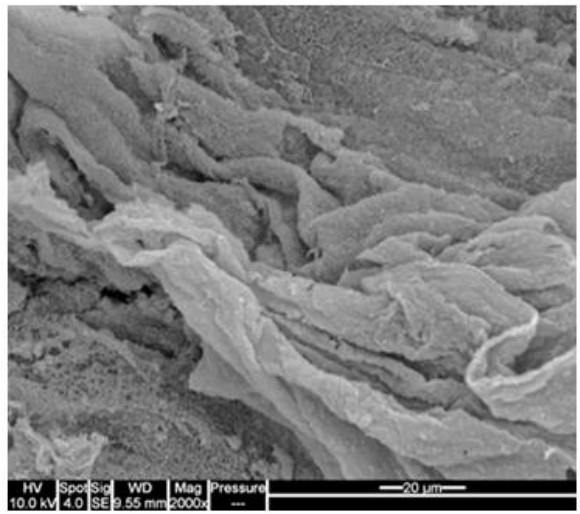

(b)

Fig. S1. Non-cellular light fraction material (a) separation of samples by centrifugation (dotted lines indicate interface between solid residue, biomass layer, non-cellular light fraction, and supernatant liquid); (b) SEM image of separated light fraction. Magnification of 2000x, $10 \mathrm{kV}$ and scale bar, $20 \mu \mathrm{m}$. 


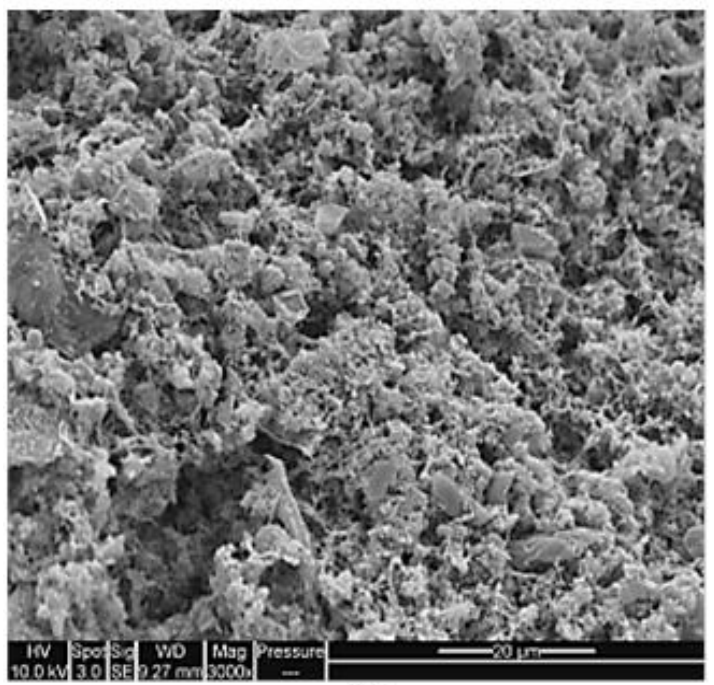

(a)

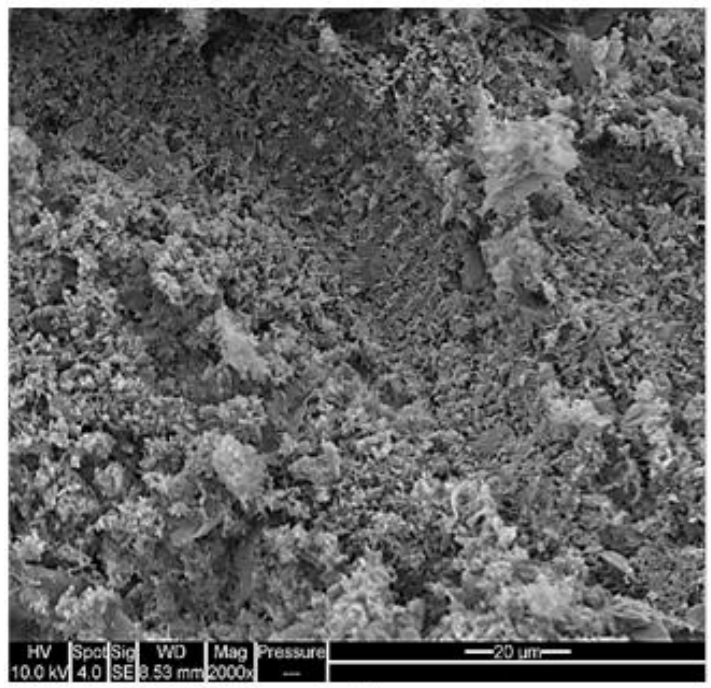

(c)

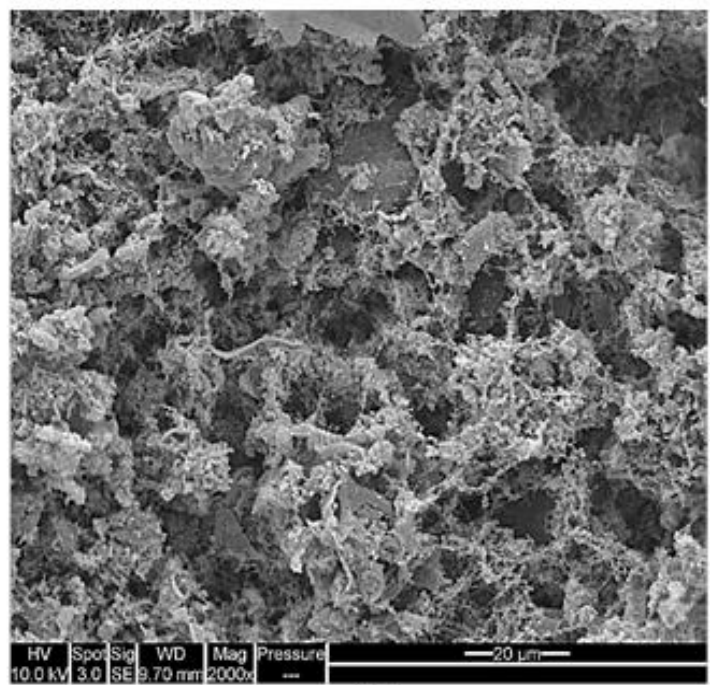

(b)

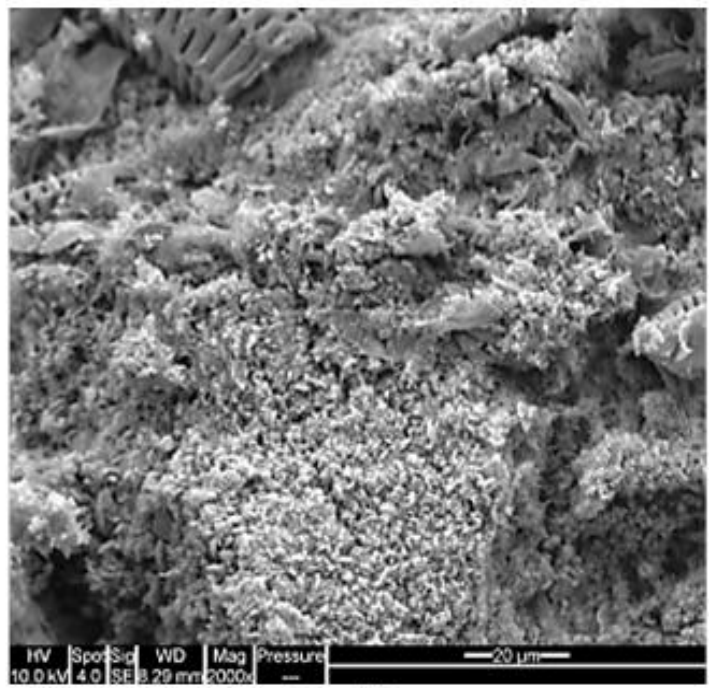

(d)

Fig. S2. SEM images of digestate from AD of SBP. (a) mesophilic, OLR $4 \mathrm{~g} \mathrm{VS}^{-1}$ day ; (b) mesophilic, OLR $5 \mathrm{~g} \mathrm{VS} \mathrm{l}^{-1} \mathrm{day}^{-1}$; c) thermophilic, OLR $4 \mathrm{~g} \mathrm{VS}^{-1} \mathrm{day}^{-1}$; d) thermophilic, OLR $5 \mathrm{~g} \mathrm{VS}^{-1}$ day $^{-1}$. Magnification of 2000x, $10 \mathrm{kV}$ and scale bar, 20 $\mu \mathrm{m}$. 
Table 1. Characteristics of sugar beet pulp

\begin{tabular}{|c|c|}
\hline Parameters & Values \\
\hline$\overline{\mathrm{TS}}(\%$ of WW) & 24.2 \\
\hline VS $(\%$ of WW $)$ & 22.6 \\
\hline VS (\% of TS) & 93.2 \\
\hline \multicolumn{2}{|c|}{ Biochemical composition $\left(g \mathrm{~kg}^{-1} \mathrm{WW}\right)$} \\
\hline Hemicellulose & 70.2 \\
\hline Cellulose & 32.2 \\
\hline Lignin & 20.0 \\
\hline Crude protein (TKN x 6.25) & 21.8 \\
\hline \multicolumn{2}{|l|}{ Elemental analysis (\% TS) } \\
\hline $\mathrm{C}$ & 42.64 \\
\hline $\mathrm{H}$ & 5.47 \\
\hline $\mathrm{N}$ & 1.79 \\
\hline \multicolumn{2}{|l|}{ Macro nutrients $\left(\mathrm{g} \mathrm{kg}^{-1} \mathrm{WW}\right)$} \\
\hline TKN $(\mathrm{N})$ & 3.48 \\
\hline Phosphorus (P) & 0.10 \\
\hline Potassium $(\mathrm{K})$ & 0.84 \\
\hline \multicolumn{2}{|l|}{ Trace elements (mg kg-1 WW) } \\
\hline Cobalt $(\mathrm{Co})$ & 0.008 \\
\hline Iron $(\mathrm{Fe})$ & 17.5 \\
\hline Molybdenum (Mo) & 0.008 \\
\hline Nickel (Ni) & 0.036 \\
\hline Selenium (Se) & 0.003 \\
\hline \multicolumn{2}{|l|}{ Other substrate parameters } \\
\hline Measured CV $\left(M J k^{-1} T S\right)$ & 16.8 \\
\hline Theoretical CV $\left(M J k^{-1} T S\right)$ & 16.1 \\
\hline
\end{tabular}


Table 2 Average values of performance and stability indicators for duplicate digesters at end of run

\begin{tabular}{|c|c|c|c|c|c|}
\hline \multirow[t]{2}{*}{ OLR } & \multirow[t]{2}{*}{ Unit g VS ${ }^{-1}$ day $^{-1}$} & \multicolumn{2}{|c|}{ Mesophilic } & \multicolumn{2}{|c|}{ Thermophilic } \\
\hline & & 4 & $5^{a}$ & 4 & 5 \\
\hline Specific biogas production & $1 \mathrm{~g}^{-1} \mathrm{VS} \mathrm{day}^{-1}$ & 0.554 & 0.549 & 0.664 & 0.681 \\
\hline Specific methane production & $1 \mathrm{CH}_{4} \mathrm{~g}^{-1} \mathrm{VS}_{\mathrm{day}}{ }^{-1}$ & 0.292 & 0.283 & 0.345 & 0.355 \\
\hline Volumetric biogas production & $11^{-1}$ day $^{-1}$ & 2.22 & 2.67 & 2.64 & 3.41 \\
\hline Volumetric methane production & $1 \mathrm{CH}_{4} \mathrm{l}^{-1} \mathrm{day}^{-1}$ & 1.17 & 1.38 & 1.37 & 1.78 \\
\hline Specific methane (VS destroyed) & $1 \mathrm{CH}_{4} \mathrm{~g}^{-1} \mathrm{VS}_{\text {destroyed }}$ & 0.358 & 0.369 & 0.391 & 0.402 \\
\hline VS destruction & $\%$ & 85.2 & 76.6 & 88.3 & 88.2 \\
\hline $\mathrm{pH}$ & - & 7.49 & 7.13 & 7.73 & 7.72 \\
\hline Total Ammonia Nitrogen & $\mathrm{mg} \mathrm{N} \mathrm{kg}^{-1} \mathrm{WW}$ & 1395 & 803 & 2094 & 1977 \\
\hline Total Alkalinity & $\mathrm{g} \mathrm{CaCO}_{3} \mathrm{~kg}^{-1} \mathrm{WW}$ & 16.1 & 11.6 & 16.9 & 16.7 \\
\hline Digestate VS & $\mathrm{g} \mathrm{VS} \mathrm{kg}^{-1} \mathrm{WW}$ & 43.1 & 67.6 & 33.8 & 33.8 \\
\hline Digestate TS & $\mathrm{g} \mathrm{VS} \mathrm{kg}^{-1} \mathrm{WW}$ & 61.5 & 89.6 & 47.6 & 47.8 \\
\hline Total VFA & $\mathrm{mg} \mathrm{l}^{-1}$ & 23 & 222 & 503 & 796 \\
\hline IA/PA ratio & - & 0.35 & 0.66 & 0.32 & 0.32 \\
\hline
\end{tabular}


Table 3. Characteristics of non-cellular light fraction material

\begin{tabular}{lr}
\hline Parameter & Value \\
\hline Elemental analysis (\%TS) & 46.47 \\
$\mathrm{C}$ & 6.18 \\
$\mathrm{H}$ & 8.09 \\
$\mathrm{~N}$ & 9.06 \\
$\mathrm{O}$ & 6.55 \\
Total Kjeldahl Nitrogen (\%TS) & \\
Biochemical composition & 43.43 \\
Crude Protein (\%TKN * 6.25) & 4.91 \\
Hemicellulose (\%TS) & 2.47 \\
Cellulose (\%TS) & 0.95 \\
Lignin (\%TS)
\end{tabular}

